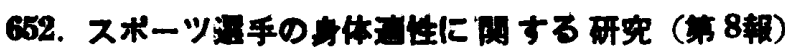

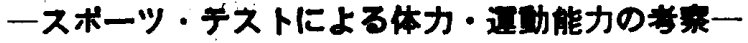
（その5）形㿟がおよはす因子梅造の变化（男子）

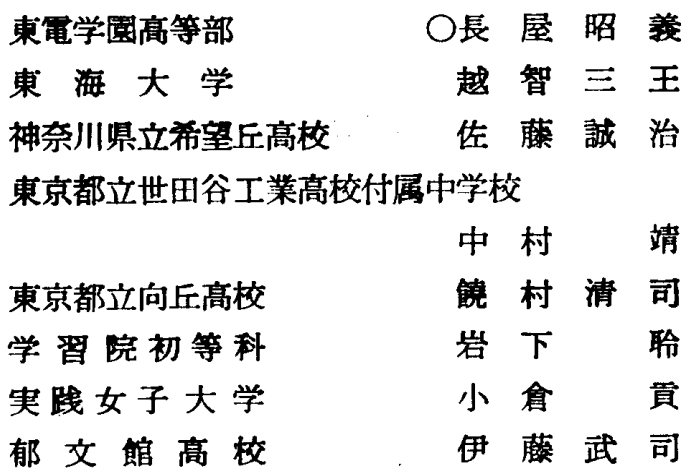

1. 目的 スボーツ・テストによつて本稿では次のよ らな観点から試みた。形䉥的要因が異なつた因子構造を 示すといら仮設を立て身長・体重をそれぞれ三区分しそ の間の相違を主成分分析法を用い検討した。

2. 研究方法 測定項目は，身長・体重とスポーツ・ テストの計 15 種目である。対象者は，高校男子 1 年 生〜3 年生までの計 300 名である. 測定方法は，スポ ーツ・テスト要領にて招こなつた。計算は大型計算機 HITAC 5020 型である.

3. 䊅果 成分分析の結果，15 因子を 100 とした割合
でフフクターA で性，身长の大 $29 \%$ ，身艮の $26.1 \%$ ， 身長の小 $28.1 \%$ である。このよな曲線はフフクター B〜O までの身長・体重についてみられた。 15 フアク ターの中でフフクターA が身長・体重ともに一番大き な值を示している．ファクター A の成分で身長（大） で次のテストが高く寄与していた。体重・反復横とび， 直垂とび・背筋・握力右， $50 \mathrm{~m}$ 走，走り巾とび・ボー

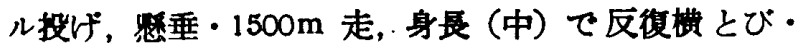
垂直とび・背筋力・握力右・左, $50 \mathrm{~m}$ 走・走り巾とび・ ボール投げ・照垂のテストが高く奇与していた，身長 （小）で体重・反復横とび・垂直とび・背筋力・暒力右・ 左，上体そらし，50m 走・走り巾とび・ボール投げの テストが高く寄与していた。このようにフフクターA に身長・体重それぞれの区別にかかわらず，体力診断テ ストの垂直とび・背筇力・握力右左運動能力テストで は，50m 走・走り巾とび・ボール投げが高く寄与して いた，他のテストにおいては，フフクターBから E の 間炇て高い奇与を示してあらわれていました．今後の 研究課題としましてテストを大きく形態，体力診断テス 卜運動能力テストと三つに分けて，それぞれの奇与率を 考察した結果ほとんど差がないという点を検討してみた W.

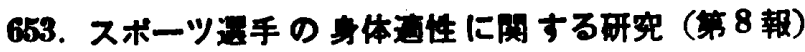

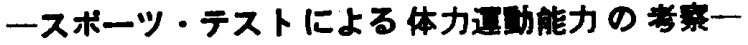
（その6）形慜がおよはす因子篗造の变化（女子） 東京都立向丘高等学校○梳 村 清 司 東海大学越智三王 神奈川県立希望ヶ丘高 佐 藤 誠 治 都立世田谷工高付属中 中 村 靖 学習院初等科岩下姶 東 電 学園高長屋昭羲 実 践女子大小倉貢 郁文館高伊藤武司

\section{1. 研究の害新・目的}

スボーツ・テスト（体力診断テスト・運動能力テス ト）(文部省）にもとついて，体力と運動能力に関した 研究事例が多々みらけるが，本稿ではこのテスト結果に つて, 主成分分析法 Principal component analysis の手法を用いて，形態的要因が異なれば，それぞれ違つ た Factor の桡造を示すであろらといら仮説のるとに, 形態の代表的指標と思われる身長及び体重を各々，大・ 中・小群に区分し，それらの間の相異を解明すべく， この研究を試みた.

\section{2. 研究の方法}

a . 被験者：高等学校女子生徒（1３ 年生） 555 人

b . 身長・体重の大・中・小群の区分
(身畏)

大: $160.0 \mathrm{~cm}$ 以上 129 人 中: $153.0 \mathrm{~cm}$ 以上 $160.0 \mathrm{~cm}$ 末満 309 人 小: $153.0 \mathrm{~cm}$ 未渾 117 人 （体重）

大: $55.0 \mathrm{~kg}$ 以上 120 人 中: $47.0 \mathrm{~kg}$ 以上 $55.0 \mathrm{~kg}$ 末満 308 人 小: $47.0 \mathrm{~kg}$ 未満 127 人 c 。テスト項目 (測定項目)

身長，体重，反復横跳・垂直跳・背筋力・握力(右) （左）・伏臥上体反乙・立位体前屈・踏台昇降運動 -

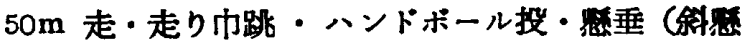
垂) $1000 \mathrm{~m}$ 走・計 15 項目

d. 湘定方法

文部省「スポーツテスト」の湘定方法によつて央施 した。

e. 計算大型電子計算機 日立 HITAC 5020 型で扰 こなつた.

\section{3. 洁果}

身長・体重の各群とも相関行列の固有值 1 より大きい Factor は，初めから数兄て5,6番目で全体の約 $65 \%$ が 説明される.1 番目の Factor には反復横跳, 垂㨁跳, 北筋力, 走り巾とびの $50 \mathrm{~m}$ 走, ハンドボール投げが閣 与している．また，各テスト項目の奇与率をみると全て の群记共通して握力が高く，反復横跳が最も低い。この ように最初の仮説を立証するための充分な結果を得るこ とができなかつた。 